\title{
ANALISIS PENGGUNAAN MODUL BERBASIS REACT PADA MATAKULIAH KALKULUS TERHADAP KEMAMPUAN KONEKSI MATEMATIS MAHASISWA
}

\author{
Alfiani Athma Putri Rosyadi ${ }^{1}$, Mayang Dintarini ${ }^{2}$, Arif Hidayatul Khusna ${ }^{3}$ \\ ${ }^{1,2,3}$ Program Studi Pendidikan Matematika, Universitas Muhammadiyah Malang \\ Email: ${ }^{1}$ alfi_rosyadi@umm.ac.id
}

\begin{abstract}
ABSTRAK
Mengintegrasikan matematika dengan konteks kehidupan sehari-hari, maupun pengetahuan awal siswa merupakan dasar untuk menjadikan belajar matematika bermakna bagi mahasiswa. Oleh karena itu, pengetahuan yang terpisah, subjek yang berbeda dan topik yang berbeda sepatutnya diramu menjadi keseluruhan yang bermakna dan mahasiswa harus dapat menghubungkan setiap bagian-bagian tersebut dengan kehidupan, minat atau kebutuhan mahasiswa tersebut. Penelitian ini bertujuan menganalisis penggunaan modul berbasis REACT pada matakuliah kalkulus terhadap kemampuan koneksi matematis mahasiswa. Subyek penelitian ini merupakan 5 mahasiswa yang telah menempuh matakuliah kalkulus diferensial. Data penelitian berupa hasil pekerjaan siswa pada modul REACT, disertai hasil wawancara untuk memperkuat hasil yang diperoleh. Analisis data menggunakan pendekatan kualitatif. Berdasarkan hasil analisis data diperoleh bahwa kemampuan koneksi matematis untuk mahasiwa berkemampuan tinggi adalah mahasiswa dapat memahami equivalen konsep atau prosedur yang sama, mengaitkan antara materi yang terdahulu dengan materi yang akan dipelajari, dan menghubungkan antar konsep matematika. Sedangkan untuk mahasiswa berkemampuan sedang mahasiswa dapat mengaitkan antara materi terdahulu tetapi belum dapat menghubungkan antar konsep matematika yang dipelajari. Untuk siswa berkemampuan koneksi yang rendah terdapat mahasiswa yang tidak dapat menyelesaikan soal yang diberikan karena kurangnya pemahaman terhadap soal.
\end{abstract}

Kata Kunci: Modul, REACT, Koneksi Matematis

\begin{abstract}
Integrating mathematics with the context of everyday life, as well as students' prior knowledge is the basis for making learning mathematics meaningful for students. Therefore, separate knowledge, different subjects and different topics should be combined into a meaningful whole and students should be able to relate each of these parts to the student's life, interests or needs. This study aims to analyze the use of the REACT-based module in calculus on the mathematical connection ability of students. The subjects of this study were 5 students who had taken the differential calculus course. Research data is in the form of student work results in the REACT module, accompanied by interviews to strengthen the results obtained. Data analysis used a qualitative approach. Based on the results of data analysis, it was found that the mathematical connection ability for high-ability students was that students could understand the equivalent of the same concept or procedure, link the previous material with the material to be studied, and connect between mathematical concepts. Whereas for students with moderate abilities, students can make a link between the previous material but have not been able to connect the mathematical concepts being studied. For students with low connection ability, there are students who cannot complete the questions given because of a lack of understanding of the questions
\end{abstract}

Keywords: Module, REACT, mathematical connection 


\section{PENDAHULUAN}

Sukiman (2012) mengemukakan media pembelajaran merupakan segala hal yang dapat mengirimkan pesan guru yang dapat merangsang pikiran, perasaan, perhatian, dan minat serta kemauan siswa sehingga tercapai tujuan pembelajaran yang telah ditetapkan dengan efektif. Guru dapat menggunakan beragam hal sebagai media pembelajaran, dari benda-benda di sekitar siswa, ataupun benda yang sengaja guru buat untuk mencapai tujuan pembelajaran. Modul merupakan salah satu yang dapat digunakan guru dalam mencapai tujuan pembelajaran. Sehingga dalam hal ini, sesuai dengan definisi di atas, modul dapat digunakan guru sebagai media pembelajaran. Hal ini dikarenakan guru dapat mengirimkan pesan/informasi untuk peserta didik agar tujuan pembelajaran tercapai melalui modul.

Modul merupakan salah satu alternatif yang dapat ditawarkan untuk mahasiswa karena pembelajarannya bersifat individual. Modul itu sendiri adalah salah satu bagian dari media pembelajaran yang dapat digunakan untuk menyampaikan informasi kepada peserta didik Hal ini diharapkan mahasiswa yang berkemampuan tinggi dan rendah dapat berkolaborasi dengan baik (Rosyadi, 2016). Kolaborasi antar mahasiswa itu sangat penting karena dapat menunjang keberhasilan proses pembelajaran (Ningrum, 2016).

Beberapa penelitian sudah menggunakan modul dalam penelitiannya antara lain yaitu (Huang, 2005; Mirkouei, Bhinge, McCoy, Haapala, \& Dornfeld, 2016; Putri Rosyadi, 2016; Rosyadi, 2018). Menurut (Huang, 2005) pedoman praktik dalam mendesain multimedia pendidikan yang berasal dari proyek lab virtual menjadi salah satu penunjang proses pembelajaran. Sejalan dengan hal tersebut, penelitian (Mirkouei et al., 2016; Putri Rosyadi, 2016; Rosyadi, 2018) juga melakukan pengembangan modul berbasis riset, penemuan terbimbing dan modul pedagogic dalam penelitiannya.

Pada dasarnya modul bisa dikolaborasikan dengan strategi dan metode yang sesuai. Kolaborasi modul tersebut tentunya mempertimbangkan kondisi mahasiswa yang ada di lapangan. Fakta yang diperoleh peneliti diperoleh data bahwa mahasiswa mengalami esulitan dalam melakukan koneksi matematis antara satu konsep dengan konsep yang lain. Mahasiswa masih belum bisa membuat keterkaitan antara materi yang dipelajari, materi lain dan kehidupan sehari-hari. Beberapa penelitian sudah mengkaji tentang koneksi matematika yaitu (Knuth, 2000; Linto, Elniati, \& Rizal, 2012). Menurut (Knuth, 2000) siswa belum bisa membuat koneksi representasi secara aljabar dan geometris dari suatu fungsi. Peneliti yang lain yaitu (Linto et al., 2012) juga mengalami masalah yang sama dalam proses koneksi matematis.

Berdasarkan fakta yang ada di lapangan diperlukan suatu media yang dapat menunjang koneksi matematis siswa. REACT merupakan salah satu strategi yang terdiri dari lima langkah yaitu: a) Relating dimana mahasiswa mengkaitkan dengan kehidupan seharihari dan konsep yang terkait, b) Experencing dimana mahasiswa melakukan aktivitas yang menunjang proses pembelajaran dan tujuan yang diharapkan, c) Applying dimana mahasiswa menerapkan konsep yang sudah dipelajari pada langkah sebelumnya, d) Cooperating yaitu mahasiswa melakukan proses diskusi dengan kelompok maupun antar kelompok dan e) Transferring adalah proses mengkaitkan dengan konsep lain yang di luar dari konteks yang dipelajari (Cahyono, Sutarto, \& Mahardika, 2017; Ismawati, 2017; Latifah \& Kusyeni, 2017; Nawas, 2018; Rosyadi, 2019; Utami, Sumarmi, Ruja, \& Utaya, 2016).

Berdasarkan permasalahan di atas maka peneliti tertarik untuk mengambil judul Analisis Penggunaan Modul Berbasis REACT Pada Matakuliah Kalkulus Terhadap Kemampuan Koneksi Matematis Mahasiswa. 


\section{METODE}

Penelitian ini merupakan penelitian deskriptif kualitatif. Subyek penelitian meupakan 5 mahasiswa Program Studi Pendidikan Matematika Universitas Muhammadiyah Malang yang telah menempuh matakuliah kalkulus diferensial. Proses pemilihan subjek menggunakan metode purposive sampling artinya disesuaikan dengan tujuan penelitian yaitu untuk mengetahui kemampuan koneksi mahasiswa. Data penelitian ini merupakan hasil pengerjaan mahasiswa pada Modul Kalkulus Integral berbasis REACT. Obyek penelitian ini merupakan kemampuan koneksi matematis mahasiswa.

Penelitian dilakukan dalam beberapa tahapan yaitu, tahap persiapan, pelaksanaan dan tahap analisis data. Tahap persiapan meliputi kaji literatur mengenai koneksi matematis, serta penggandaan modul Kalkulus berbasis REACT. Tahap pelaksanaan meliputi, memilih 5 mahasiswa yang kemudian meminta mahasiswa tersebut untuk menyelesaikan modul secara mandiri, serta melakukan wawancara terhadap mahasiswa tersebut untuk mengonfirmasikan jawaban mahasiswa. Tahap selanjutnya adalah menganalisis hasil pengerjaan mahasiswa berdasarkan indikator koneksi matematis secara kualitatif, yaitu Reduksi data dimana memilih data hasil pengerjaan mahasiswa yang dapat disajikan, Penyajian Data berupa paparan hasil pengerjaan mahasiswa dikaitkan dengan 5 indikator koneksi matematis, menurut Ramdani (2012) yaitu: mencari dan memahami hubungan berbagai representasi konsep dan prosedur; menggunakan matematika dalam bidang studi lain atau kehidupan sehari-hari; memahami representasi ekuivalen konsep atau prosedur yang sama; mencari koneksi satu prosedur ke prosedur lain dalam representasi yang ekuivalen; serta menggunakan koneksi antar topik matematika, dan antara topik matematika dengan topik lain.

\section{HASIL DAN PEMBAHASAN}

Hasil penelitian didasarkan pada hasil pengerjaan siswa pada modul yang berbasis REACT. Modul terdiri dari kegiatan belajar 1, kegiatan belajar 2, dan kegiatan belajar 3 . asing-masing kegiatan memuat aspek REACT. Pada bagian kegiatan belajar 1, modul ini membahas tentang integral tentu. Sedangkan pada kegiatan belajar 2 membahas entang teorema dasar kalkulus pertama. Selanjutnya, pada kegiatan belajar 3 membahas tentang teorema kalkulus dua. Secara umum hasil dari penelitian menunjukkan kemampuan koneksi matematis dari kelima subjek uji coba.

Berdasarkan hasil penelitian mahasiswa terlihat sudah dapat memahami equivalen konsep atau prosedur yang sama. Hal ini terlihat pada tahap Transferring yaitu ketika mahasiswa diminta untuk mencari sebuah artikel yang terkait dengan konsep integral tertentu. Terlihat pada Gambar 1 mahasiswa dapat menentukan dan mengaitkan konsep integral tertentu yang terdapat pada artikel dengan konsep integral yang telah dipelajari. Hal ini juga berlaku pada konsep teorema dasar kalkulus pertama dan kedua. Sejalan dengan hasil penelitian (Lestari, Rohaeti, \& Purwasih, 2016; Tasni \& Susanti, 2017; Warih, Parta, \& Rahardjo, 2016) yang menyatakan bahwa kemampuan koneksi dapat terlihat dari subjek dapat mengnali konsep-konsep yang terdapat pada permasalahan yang diberikan. 


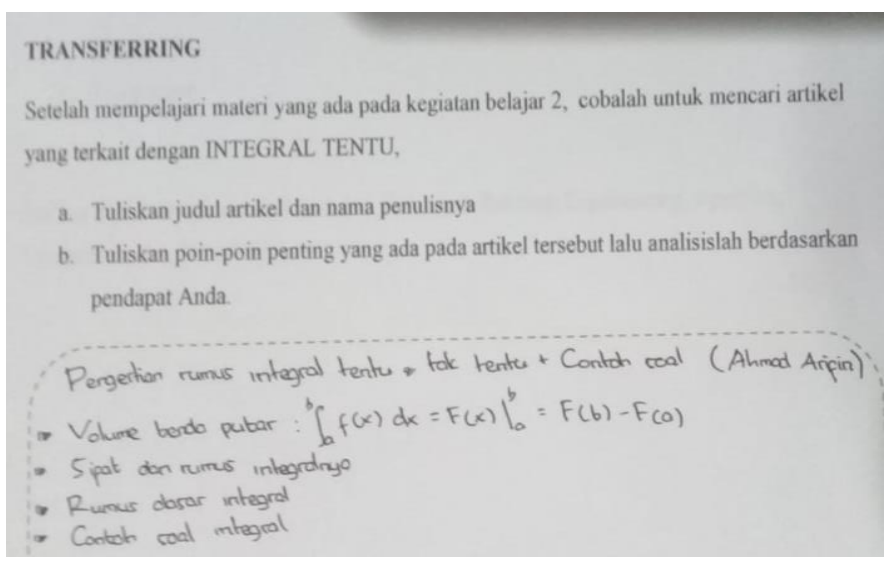

Gambar 1

Indikator koneksi matematis lain yang terlihat adalah mahasiswa dapat melihat keterkaitan antara materi yang terdahulu dengan materi yang akan dipelajari (Sugandi \& Akbar, 2019). Hal ini terlihat dari hasil pengerjaan mahasiswa pada tahap Relating. Mahasiswa dapat menggunakan konsep definisi turunan dan konsep integral tentu untuk membuktikan teorema dasar kalkulus pertama. Hal ini terlihat pada gambar 2 di bawah ini.

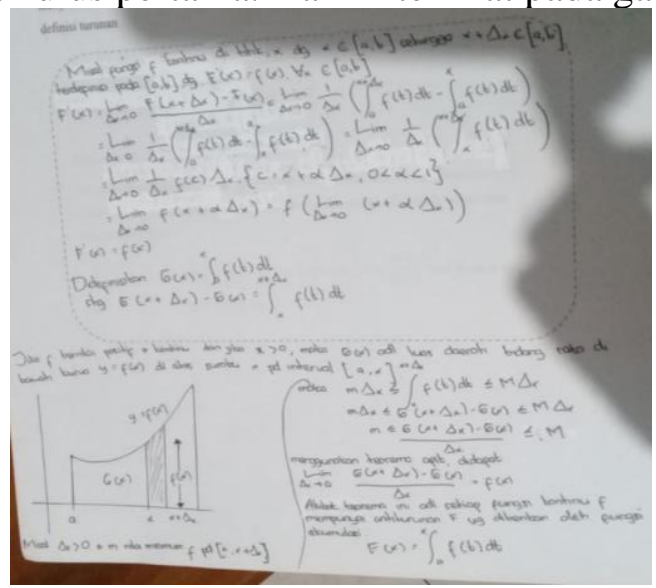

Gambar 2

Pada tahap Relating mahasiswa dapat menghubungkan antar konsep matematika. terlihat pada Gambar 3 mahasiswa dapat menggubungkan konsep luas persei panjag dengan konsep aljabar dalam menentukan luas dari masing-masing persegi.

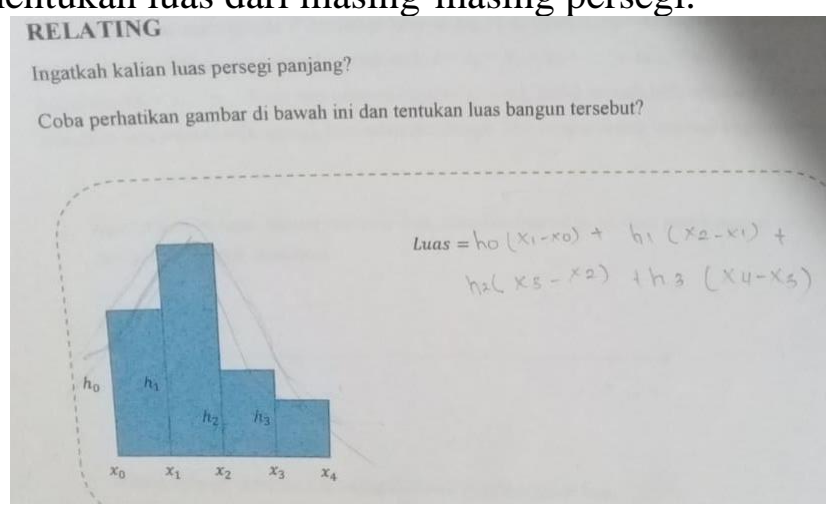

\section{Gambar 3}

Secara keseluruhan mahasiswa memiliki kemampuan koneksi matematis yang baik. Hal ini terlihat pada beberapa unsur REACT seperti Tranferring, Relating, dan Experiencing mahasiswa sudah menujukkan kemampuan koneksi matematis. Meskipun terdapat satu mahasiwa yang masih bingung dalam mengerjakan hasil. Hal ini terlihat dari tidak adanya jawaban pada modul tersebut. Hasil wawancara menunjukkan bahwa mahasiswa tersebut 
mengalami kesulitan dalam memahami soal yang diberikan. Kesulitan yan dialami yaitu kesulitan dalam memaknai kalimat yang terdapat pada soal. Ini menunjukkan bahwa kemampuan komunikasi masih mengalami kesulitan sehingga diperlukan solusi yang sesuai (Knuth, 2000; Linto et al., 2012). Hal ini sejalan dengan penelitian (Nurhayati, 2013) yang menyatakan bahwa siswa kesulitan dalam menyelesaikan soal karena sisa sulit memahami kalimat yang terdapat pada soal.

\section{KESIMPULAN DAN SARAN}

Berdasarkan hasil yang diperleh dapat disimpulkan melalui penggunaan modul berbasis REACT kemampuan koneksi matematis untuk mahasiwa berkemampuan tinggi adalah mahasiswa dapat memahami equivalen konsep atau prosedur yang sama, mengaitkan antara materi yang terdahulu dengan materi yang akan dipelajari, dan menghubungkan antar konsep matematika. Sedangkan untuk mahasiswa berkemampuan sedang mahasiswa dapat mengaitkan antara materi terdahulu tetapi belum dapat menghubungkan antar konsep matematika yang dipelajari. Untuk siswa berkemampuan koneksi yang rendah terdapat mahasiswa yang tidak dapat menyelesaikan soal yang diberikan karena kurangnya pemahaman terhadap soal.

\section{DAFTAR RUJUKAN}

Cahyono, B. A. D., Sutarto, S., \& Mahardika, I. K. (2017). Model Pembelajaran REACT (Relating,Experiencing,Applying,Cooperating, Transfering) disertai Media Video Kejadian Fisika Terhadap Keterampilan Proses Sains dan Hasil Belajar Siswa dalam Pembelajaran Fisika di SMA. Jurnal Edukasi. https://doi.org/10.19184/jukasi.v4i3.6155

Huang, C. (2005). Designing high-quality interactive multimedia learning modules. Computerized Medical Imaging and Graphics. https://doi.org/10.1016/j.compmedimag.2004.09.017

Ismawati, R. (2017). Strateg1 React dalam Pembelajaran Kımıa SMA. Indonesian Journal of Science and Education.

Knuth, E. J. (2000). Student understanding of the cartesian connection: An exploratory study. Journal for Research in Mathematics Education. https://doi.org/10.2307/749655

Latifah, S., \& Kusyeni, M. (2017). Efektivitas Strategi REACT (Relating, Experiencing, Applying, Cooperating, Transfering) Terhadap Hasil Belajar dan Keterampilan Proses Sains di SMP N 22 Bandar Lampung. Jurnal Penelitian Pembelajaran Fisika. https://doi.org/10.26877/jp2f.v8i2.1627

Lestari, R. S., Rohaeti, E. E., \& Purwasih, R. (2016). Profil Kemampuan Koneksı Matemat1s Siswa SMP dalam Menyelesa1kan Soal Bangun Ruang S1s1 Datar Ditınjau dar1 Kemampuan Dasar. Jurnal Ilmiah Pendidikan Matematika, 3(1), 51-58.

Linto, R. L., Elniati, S., \& Rizal, Y. (2012). Kemampuan Koneksi Matematis dan Metode Pembelajaran Quantum Teaching dengan Peta Pikiran. Jurnal Pendidikan Matematika. https://doi.org/10.13989/j.cnki.0517-6611.2015.10.011

Mirkouei, A., Bhinge, R., McCoy, C., Haapala, K. R., \& Dornfeld, D. A. (2016). A Pedagogical Module Framework to Improve Scaffolded Active Learning in Manufacturing Engineering Education. Procedia Manufacturing. https://doi.org/10.1016/j.promfg.2016.08.088

Nawas, Abu. (2018). Contextual Teaching and Learning (CTL) Approach through REACT Strategies on Improving the Students ' Critical Thinking in Writing. International Journal of Applied Management Science.

Ningrum, P. (2016). Menıngkatkan Keaktıfan dan Kemampuan Berpıkır Kreatıf Melaluı Pembelajaran Kolaboratıf Berbasıs Masalah Materı Kelarutan dan Hasıl Kalı 
Kelarutan (KSP) Siswa Kelas XI SMA Negerı 10 Semarang. JURNAL PENDIDIKAN SAINS (JPS). https://doi.org/10.26714/jps.4.1.2016.17-28

Nurhayai. (2013). Penerapan Langkah-Langkah Polya Untuk Meningkatkan Hasil Belajar Siswa Dalam Menyelesaikan Soal Cerita Himpunan Di Kelas VII Smp Nasional Wani. Elektronik Pendidikan Matematika Tadulako.

Putri Rosyadi, A. A. (2016). Pengembangan Modul Pembelajaran Menggunakan Pendekatan Penemuan Terbımbing pada Matakuliah Kalkulus. JPM: Jurnal Pendidikan Matematika. https://doi.org/10.33474/jpm.v2i1.201

Putri Rosyadi, A. A. (2019). Pengembangan Buku Ajar Aplikasi Matematika Menggunakan Pendekatan REACT. JPM : Jurnal Pendidikan Matematika. https://doi.org/10.33474/jpm.v5i1.2630

Ramdani, Y. (2012). Pengembangan Instrumen dan Bahan Ajar untuk Menıngkatkan Kemampuan Komunıkası, Penalaran, dan Koneksı Matematıs dalam Konsep Integral Oleh: Yani Ramdani. Jurnal Penelitian Pendidikan, 13(1), 44-52.

Rosyadi, A. A. P. (2018). Pengembangan modul berbasis riset pada mata kuliah kalkulus untuk meningkatkan kreativitas mahasiswa. Math Didactic: Jurnal Pendidikan Matematika. https://doi.org/10.33654/math.v4i2.99

Sugandi, A. I., \& Akbar, P. (2019). Efektıvitas Penerapan Strateg1 REACT Terhadap Kemampuan Koneksı Matematıs dan Self-Efficacy Siswa SMP. Journal Cendekia: Jurnal Pendidikan Matematika, 03(02), 423-430.

Sukiman. (2012). Pengembangan Media Pembelajaran. Yogyakarta: Pedagogia.

Tasni, N., \& Susanti, E. (2017). Membangun koneksi matematis siswa dalam pemecahan masalah verbal. BETA: Jurnal Tadris Matematika, 10(1), 103-116.

Utami, W. S., Sumarmi, Ruja, I. N., \& Utaya, S. (2016). React ( Relating, Experiencing, Applying , Cooperative , Transferring ) Strategy to Develop Geography Skills. Journal of Education and Practise.

Warih, P. D., Parta, I. N., \& Rahardjo, S. (2016). Analisis Kemampuan Koneksi Matematis Siswa Kelas VIII pada Materi Teorema Pythagoras. Prosiding Konferensi Nasional Penelitian Matematika Dan Pembelajarannya [KNIP I]. 